Int. J. Morphol.,

33(1):158-163, 2015.

\title{
Body Mass Index and Volume of Fat Tissue of Unemployed Men in the Tuzla Canton
}

\author{
Índice de Masa Corporal y Volúmen de Tejido Graso \\ en Hombres Desempleados de Tuzla Canton
}

Alen Kapidzic*; Sefik Hasukic**; Jasmin Mehinovic*; Almir Atikovic*; Amra Nozinovic Mujanovic* \& Edin Mujanovic*

KAPIDZIC, A.; HASUKIC, S.; MEHINOVIC, J.; ATIKOVIC, A.; MUJANOVIC, A. N. \& MUJANOVIC, E. Body mass index and volume of fat tissue of unemployed men in the Tuzla Canton. Int. J. Morphol., 33(1):158-163, 2015.

SUMMARY: The main objective of this study was to obtain information on indicators of obesity among the unemployed male subjects from the Tuzla Canton. Also, we wanted to determine whether there are significant differences in the observed parameters between subjects in relation to age. The main criterion for the selection of test subjects is that they are unemployed. This is because we felt that those persons have more free time for practicing sports and recreational activities, and there is a very small number of studies in the area of Tuzla Canton with the characteristics of the sample. For the purpose of this research we applied analysis of percentage/ratio, t-test for independent samples and the Mann-Whitney U Test. Applied analysis showed that the increased value of Body Mass Index (BMI) and to the account of increased amounts of body fat has $31.5 \%$ of the respondents. It also found that there are significant differences in the variables Body Mass Index (BMI), body fat percentage (\% FAT) and the total weight of fat mass (in kg) in the body (FATMAS-kg) in favor of the subjects belonging to the older age group. The results indicate the existence of the problem of obesity in males from Tuzla Canton, especially in the older age group. It is therefore necessary in adolescence or even earlier, to start with education and systematic practice of sports and recreational activities with respect to dietary habits.

KEY WORDS: Body Mass Index; Fat Tissue; Unemployed Men.

\section{INTRODUCTION}

Occurrence of obesity and nutrition disorders becomes more frequent both, in the world and in our country (Argnani et al., 2008). In this regard, obesity presents the leading health problem for people all over the world, in the developed countries, but even more so in countries in transition. Recently, a lot of attention was dedicated to obesity and it is considered to be related with the appearance of cardio-vascular diseases and metabolic disorders (Crnobrnja et al., 2012). Still, it needs to be emphasised that obesity is less frequently caused by metabolic disorders and more frequently with lifestyles. Modern definition of obesity understands increase of total weight, and not the total body mass, to the extent that leads to serious health problems and a series of complications, and occurs as a result of the imbalance between energy intake and energy expenditure (World Health Organization, 2000). It is known that the result of the increased deposit of excess energy in the form of fat in adipose tissue leads to the development of obesity. Thus, fat tissue changes its functional characteristics through modified production of adipokine, which has a significant role in the development of obesity-related problems (Crnobrnja et al.). When discussing the trends in body mass index rise, it is considered that the socio-economic factors contribute to the manifestation of obesity (Jakimaviciene \& Tutkuviene, 2007; Kirchengast et al., 2004; Zsidegh et al., 2007). Although the genetic factors can have a significant influence on obesity, the conditions of the environment present the main factors leading to besity. Researches stating the data from the American National Institute of Health show that $60.5 \%$ of the adult population is overweight, while $23.9 \%$ show obesity of the 1 st and 2 nd degree of obesity, and 3.0\% have the 3rd degree of obesity (extremely obese) (Music'-Milanovic' et al., 2012). The frequency of obesity is brought in direct relation with the physical activity, i.e. inactivity. Unlike people with normal body mass, those with excessive body mass are less physically active (Dietz \& Gortmaker, 1985; Skinner et al., 2008). It is therefore very important for people of all ages to

\footnotetext{
* Faculty of Physical Education and Sport, University of Tuzla, Tuzla, Bosnia and Herzegovina.

** University Clinical Center Tuzla, Department of Surgery, Tuzla, Bosnia and Herzegovina.
} 
engage in physical activities as much as possible, to reduce the occurrence of obesity. The decrease of obesity and increase of physical activity has a direct influence on delaying the occurrence of various diseases (Toraman \& Ayceman, 2005). The European Commission's Platform for Action on Diet, Physical Activity and Health from 2006 also deals with combating obesity (August et al., 2008). It regulates the measures for prevention of obesity for countries of the European region. Precise data on the number of obese persons provide the information to assist us in finding the most efficient prevention measures for combating this problem (August et al.). A percentage of obese children in primary schools and those with poor nutrition habits present a large problem in Bosnia and Herzegovina (Dinarevic et al., 2011). Physical inactivity and poor nutrition habits tend to continue during the adolescence. The adolescents are occupied with their looks, and deviation from the ideal look can lead to low self-esteem and the overall health sensitivity (Sujoldzic \& De Lucia, 2007). Considering the above mentioned, we wanted to gain the information on the indicators of obesity of unemployed persons in the Tuzla Canton and to establish whether there are significant differences in relation to the age of the subjects. The information can serve as a relevant parameter to all institutions which should take care of this problem, in order to take an adequate role in its solving.

\section{MATERIAL AND METHOD}

Participants. The testing was conducted with $(n=444)$ highly educated unemployed persons from the area of the Tuzla Canton (TC). The test subjects taken as the sample do not have any expressed physical or health aberrations. Average, body height was $181.7 \pm 6.4(\mathrm{~cm})$, body weight was $83.4 \pm 11.2$ (kg) and age was 25.2 \pm 3.7 . The test subjects were tested within the project organised by the University Sport Association of the University of Tuzla. The title of the project was "Measurement of Morphological Characteristics". All interested participants were able to access the testing at the Faculty of Physical Education and Sports of the University of Tuzla, to get information about their morphological characteristics. The test subjects, who stated that they are unemployed, are taken into account for this study. The sample has been divided by the criterion of age in the two groups; younger and older. The group "younger" contained 211 test subjects aged 20-24 years, and in the group "older" included 233 subjects aged $25-34$ years. 233 test subjects in the age range from 25 to 34 years. The research was approved by the Ethics Committee of the University of Tuzla, in accordance with the principles of the Helsinki Declaration on Human Rights.
Variables. The measuring instrument used for the testing was the Body Composition Analyser Tanita TBF-300a, Tokyo, Japan. The parameters measured by this instrument and considered in this research include: WEIGHT - body mass $(\mathrm{kg}), \mathrm{BMI}$ - body mass index $\left(\mathrm{kg} / \mathrm{m}^{2}\right)$, FAT\% - body fat percentage $(\%)$, FAT MASS - total weight of fat in the body $(\mathrm{kg})$, FAT\% MIN - recommended minimum value of body fat percentage in relation to the age, FAT\% MAX recommended maximum value of body fat percentage in relation to the age, FAT MASS MIN - recommended minimum value of fat in the body in relation to the age, weight and height (kg), FAT MASS MAX - recommended maximum value of fat in the body in relation to the age, weight and height $(\mathrm{kg})$. The Body Composition Analyser Tanita TBF - 300a requires manual data entry on body height (HEIGHT - body height in $\mathrm{cm}$ ) and age (AGE - age group by years). In relation to the said, we have measured the height of the test subjects using Martin's anthropometer, with measuring accuracy of $0.01 \mathrm{~m}$.

Testing procedure. Each testing was carried out in the Diagnostic Centre of the Faculty of Physical Education and Sports, of the University of Tuzla. The test subjects who were tested had to have the appropriate sports equipment: shorts and sports shirt. During the testing, the test subjects did not have sneakers or socks on their feet. It needs to be emphasised that two measurers carried out every testing. One of them carried out measuring using Martin's anthropometer, and the other carried out measurement at the Body Composition Analyser Tanita TBF-300a. During the testing, the test subjects were first measured for body height (Height). After the measurement of the body height, the result was manually entered into the Body Composition Analyser Tanita TBF-300a. After the entry of this data, the following entry was on the age of the test subjects. After the input of these parameters, the test subjects' step on the Tanita and stand still until the procedure of testing is completed.

Data analysis. Besides the quantitative measurement, this research used the analysis of percentage and proportions to determine the frequency of occurrence for different characteristics. The T-test was used for independent samples and Mann-Whitney U Test was used for variables expressed in percentages with the aim to determine differences in body structure.

\section{RESULTS}

The data collected during the research are shown in the Table I, also showing the values of the BMI valid for this European area (Meta Metasys, 2010). Based on the given 
Table I. Standard value of body mass index (BMI) for the European region and the presence of obesity in subjects according to the values of BMI in Tuzla Canton.

\begin{tabular}{lcccc}
\hline Body Mass Index $\left(\mathbf{k g} / \mathbf{m}^{2}\right)$ & $\begin{array}{c}\text { Standard BMI values } \\
\text { for European area }\end{array}$ & Body Mass Index $(\mathbf{k g} / \mathbf{m} \mathbf{2})$ & $\%$ \\
\hline Underweight & $<20$ & Underweight & $18.1-19.9$ & $2.8 \%$ \\
Normal weight & $20-25$ & Normal weight & $20.0-24.9$ & $42.1 \%$ \\
Overweight & $25-30$ & Overweight & $25.0-29.9$ & $51.6 \%$ \\
Obese Class I & $30-35$ & Obese Class I & $30.1-33.2$ & $2.8 \%$ \\
Obese Class II & $35-40$ & Obese Class II & 35.1 & $0.7 \%$ \\
Obese Class III & $>40$ & Obese Class III & --- & --- \\
\hline
\end{tabular}

results we see that $2.8 \%$ of the tested subjects have a Body Mass Index (BMI) indicating that they belong into the group of underweight persons. Among the tested subjects, $42.1 \%$ belong into the group with normal body weight, and $51.6 \%$ belong into the group of overweight persons. Even $2.8 \%$ of the tested subjects, based on the BMI, belong into the group of obese class I persons, and $0.7 \%$ of tested subjects are in the group obese class II persons.

Results of the analysis also shows that $31.5 \%$ of the tested subjects has the value of fat tissue presented in the percentage and in kilograms above the predicted values of minimum and maximum values (Table II). The results presented in the Tables III-V shows the existence of statistically significant differences between the groups based on the variables FAT MASS, BMI and FAT\%. Noted differences are in favor of the older group of tested subjects aged 25-34 years.

Table II. The presence of obesity in subjects according to the amount of body fat tissue.

\begin{tabular}{lc}
\hline Variables & Above the recommended value \\
\hline FAT $\%$ & $31.5 \%$ \\
FAT & $31.5 \%$ \\
MASS (kg) & --- \\
\hline
\end{tabular}

Legend: FAT\% (body fat percentage); FAT MASS (total weight of fat in the body (in $\mathrm{kg}$ ).

\section{DISCUSSION}

The occurrence of obesity results through development of complications, certainly disrupting the quality of life of each individual (Kirchengast \& Marosi, 2008). Thus, prevention of obesity of young persons should present a strategic goal (Crnobrnja et al.). It is of specific interest to note that the test subjects of our research are unemployed persons. We have considered that the unemployed persons have more time to organize their free time in a more quality manner. Through the researches so far, it was seen that the test subjects who practiced physical activity had lower value of the BMI (Dietz \& Gortmaker). Researches were conducted with the aim to compare the male and female in forms of physical activity. It was determined that the male test subjects were physically more active than their female age peers (Kirchengast \& Marosi). In accordance with the results of this research, we can see that $31.5 \%$ of test subjects have increased level of fat tissue in comparison to minimum and maximum recommended values. We can say that these test subjects have an increased value of the Body Mass Index primarily based on the amount of the fat tissue. In accordance with these indicators, it is noted that the test subjects should dedicate more time to physical activities. More frequent physical activity can contribute to prevention of obesity in a very short period of time. The discoveries showing that an eight-week programme of Pilates exercise contributes to reduction of the Body Mass Index, as well as body mass free fat tissue contribute to this finding (Cakmakci, 2011). The reason for such a high percentage of obese persons can be found in the social status of the test subjects (Jakimaviciene \& Tutkuviene). Authors Kirchengast et al., determined in their research that the excessive body weight and obesity are more present among the persons of poorer social status. The reason for such high percentage of obesity probably lies in higher preference for sedentary activities. In studies (Delas et al., 2008; Basaldúa \& Chiquete, 2008) it was determined that the male test subjects are less active than female test subjects. The reason for this lies in the fact that female persons pay more attention to their looks in comparison to men. As Bosnia and Herzegovina is a country with high percentage of unemployed persons, and this situation keeps worsening, the living standard is under the average of the countries in the region. In relation to the above, we can not expect for the interest in physical activities to be significantly higher, when the primary existential conditions have not been met (Jakimaviciene \& Tutkuviene; Sujoldzic \& De Lucia). It is known that there is not one anthropological characteristic to which physical activity has no positive impact (Beedie et 
Table III. Mean values of body fat mass and BMI in the studied groups.

\begin{tabular}{llcccc}
\hline Variables & Group & n & M & SD & Std. Error Mean \\
\hline \multirow{2}{*}{ FAT MASS } & Younger & 211 & 14.435 & 5.235 & 0.360 \\
& Older & 233 & 16.597 & 5.919 & 0.387 \\
BMI & Younger & 211 & 24.759 & 2.553 & 0.175 \\
& Older & 233 & 25.606 & 2.748 & 0.180 \\
\hline
\end{tabular}

Legend: $\mathrm{n}$ (number of study participants); M (mean); SD (standard deviation); BMI (Body

mass index); FAT MASS (total weight of fat in the body (in $\mathrm{kg}$ ).

Table IV. The values T-test for independent samples for studied groups.

\begin{tabular}{|c|c|c|c|c|c|c|c|c|c|}
\hline \multirow{3}{*}{ Variables } & \multicolumn{2}{|c|}{$\begin{array}{c}\text { Levene's Test for } \\
\text { Equality of Variances }\end{array}$} & \multicolumn{7}{|c|}{ T-test for Equality of Means } \\
\hline & \multirow{2}{*}{$\mathbf{F}$} & \multirow{2}{*}{ Sig. } & \multirow{2}{*}{$\mathbf{t}$} & \multirow{2}{*}{ df } & \multirow{2}{*}{$\begin{array}{c}\text { Sig. } \\
(2 \text {-tailed })\end{array}$} & \multirow{2}{*}{$\begin{array}{c}\text { Mean } \\
\text { Difference }\end{array}$} & \multirow{2}{*}{$\begin{array}{l}\text { Std. Error } \\
\text { Difference }\end{array}$} & \multicolumn{2}{|c|}{$95 \%$ confidence } \\
\hline & & & & & & & & Upper & Lower \\
\hline \multirow[t]{2}{*}{ FAT MASS } & 0.017 & 0.896 & -4.059 & 442 & 0.000 & -2.162 & 0.532 & -3.208 & -1.115 \\
\hline & & & -4.084 & 441.762 & 0.000 & -2.162 & 0.529 & -3.202 & -1.121 \\
\hline \multirow[t]{2}{*}{ BMI } & 0.209 & 0.648 & -3.353 & 442 & 0.001 & -0.846 & 0.252 & -1.343 & -0.350 \\
\hline & & & -3.365 & 441.700 & 0.001 & -0.846 & 0.251 & -1.341 & -0.352 \\
\hline
\end{tabular}

Legend: BMI (Body mass index); FAT MASS (total weight of fat in the body (in $\mathrm{kg}$ ).

Table V. The values of Mann-Whitney U Test for body fat percentage for studied groups.

\begin{tabular}{llcccccc}
\hline Variable & Group & $\mathbf{n}$ & $\begin{array}{c}\text { Mean } \\
\text { Rank }\end{array}$ & $\begin{array}{c}\text { Sum of } \\
\text { Ranks }\end{array}$ & Z & $\begin{array}{c}\text { Asymp. Sig. } \\
\text { (2-tailed) }\end{array}$ & Mann-Whitney U \\
\hline FAT\% & Younger & 211 & 191.29 & 40361.50 & -4.878 & 000 & 17995.500 \\
& Older & 233 & 250.77 & 58428.50 & --- & --- & --- \\
& Total & 444 & --- & --- & --- & --- & -- \\
\hline
\end{tabular}

Legend: n (number of study participants); FAT\% (body fat percentage).

al., 2000). The results presented in Tables III-V show the existence of statistically significant differences between the groups based on the variables FAT MASS, BMI and FAT\%. Noted difference is in favour of the older group of tested subjects aged 25-34 years. Thus, we can say that it is necessary to start at the age of adolescence, and even earlier, with education and systematic practicing of sport and recreational activities, along with attention paid to nutritive habits. Such systematic work will finally contribute to creation and maintenance of positive habits related to physical activities and nutrition. It is evident that BMI values vary in relation to the age of test subjects, regional variability, and many other factors. Some of the current researches also contribute to this discussion (Argnani et al.; Kirchengast et $a l$.). It is possible to influence on the measured variables in this research during a lifespan, because they are not genetically highly specific. This understands more physical activities during free time of each individual, as well as a lasting attention paid to the nutrition. In accordance with the said, modern findings clearly show that the changes in the way of life and maintenance of normal physical weight during childhood can reduce the risk of metabolic disorders and cardio-vascular diseases during the adulthood (Steinberger et al., 2003). Considering the fact that the living standard of the majority of the Bosnia and
Herzegovina's population is rather low, we can say that the existential problems prevail in lives of the test subjects of this research, depending on their social status. All of this decreases the time spent on sport and recreational activities during free time of a young person (Rogulj et al., 2011; Nikolaidis, 2012). It needs to be emphasised that a reason for such high percentage of obese persons can be found in the nutritional habits, too. Some of the current studies (Chaput et al., 2010; Epstein \& Goldfield, 1999) confirm that the nutrition largely contributes to occurrence of obesity. We must emphasise that the opportunities for sport and recreational activities in the Tuzla Canton are limited. There are several obvious reasons for it: lack of infrastructure for sport and recreational activities, no strategy for development of sport and recreational activities, underdeveloped awareness on the significance of recreational activities. Surely, there are such facilities that provide recreational activities, but they require significant funding.

\section{CONCLUSION}

The results of this research indicate the existence of the obesity problem with test subjects from the area of the 
Tuzla Canton who were included in the test sample for this research. In addition, it was established that the test subjects in the older age group have increased values of treated parameters in comparison to those in the younger age group. The results of the research clearly indicate the need for each person to organize their free time in the best possible way. This understands involvement in sport and recreational activities in free time, in addition to paying attention to the nutrition. In accordance to the above, there is a justified need and an obligation of responsible institutions to direct their attention to prevention of obesity. The preventive measures would be related to improvement of infrastructure, production of strategy of development of sport and recreational activities, promotion of significance of sport and recreational activities and their impact on the health of humans. Along with all of the given statements, engaging the adequate human resources would contribute to rising of quality of life of the citizens of the Tuzla Canton.

KAPIDZIC, A.; HASUKIC, S.; MEHINOVIC, J.; ATIKOVIC, A.; MUJANOVIC, A. N. \& MUJANOVIC, E. Indice de masa corporal y volumen de tejido graso en hombres desempleados de Tuzla Canton. Int. J. Morphol., 33(1):158-163, 2015.

RESUMEN: El objetivo de este estudio fue obtener información sobre los indicadores de obesidad entre los varones desempleados en Tuzla Canton. Además, determinar si existen diferencias significativas en los parámetros observados entre los sujetos en relación con la edad. El criterio principal para la selección de los sujetos fue que se encontraran desempleados. Esto debido a que estas personas tienen más tiempo libre para la práctica de actividades deportivas y recreativas, y existe un número muy pequeño de estudios en el área de Tuzla Canton con las características de esta muestra. A los efectos de esta investigación se aplicó el análisis de porcentaje/proporción, prueba t, muestras independientes y la prueba U de Mann-Whitney. El análisis aplicado mostró que el aumento del valor de índice de masa corporal (IMC) y una mayor cantidad de grasa corporal se observó en un 31,5\% de los encuestados. También se encontró que existen diferencias significativas en las variables del IMC, porcentaje de grasa corporal y en el peso total de la masa de grasa (en kg) en el cuerpo en los sujetos pertenecientes al grupo de mayor edad. Los resultados indican la existencia del problema de la obesidad en los varones de Tuzla Canton, especialmente en el grupo de mayor edad. Por ello es necesario en la adolescencia, e incluso antes, comenzar con la educación y la práctica sistemática de actividades deportivas y recreativas con respecto a los hábitos alimenticios.

PALABRAS CLAVE: Índice de masa corporal; Tejido graso; Hombres desempleados.

\section{REFERENCES}

Argnani, L.; Toselli, S. \& Gualdi-Russo, E. Body image and growth in Italy. Coll. Antropol., 32(2):413-8, 2008.

August, G. P.; Caprio, S.; Fennoy, I.; Freemark, M.; Kaufman, F. R.; Lustig, R. H.; Silverstein, J. H. \& Speiser, P. W.; Styne, D. M.; Montori, V. M. \& Endocrine Society. Prevention and treatment of pediatric obesity: an endocrine society clinical practice guideline based on expert opinion. J. Clin. Endocrinol. Metab., 93(12):4576-99, 2008.

Basaldúa, N. \& Chiquete, E. Common predictors of excessive adiposity in children from a region with high prevalence of overweight. Ann. Nutr. Metab., 52(3):227$32,2008$.

Beedie, C. J.; Terry, P. C. \& Lane, A. M. The profile of mood states and athletic performance: Two meta-analyses. $J$. Appl. Sport Psychol., 12(1):49-68, 2000.

Cakmakci, O. The effect of 8 week pilates exercise on body composition in obese women. Coll. Antropol., 35(4):1045-50, 2011.
Chaput, J. P.; Sjödin, A. M,; Astrup, A.; Després, J. P.; Bouchard, C. \& Tremblay, A. Risk factors for adult overweight and obesity: the importance of looking beyond the 'big two'. Obes. Facts, 3(5):320-7, 2010.

Crnobrnja, V.; Srdic, B.; Stokic, E.; Dujmovic, F. \& Andrejic, B. Analysis of obesity prevalence in students from Novi Sad. Med. Pregl., 65(3-4):133-7, 2012.

Delas, N.; Tudor, A.; Ruzic, L. \& Sestan, B. Obesity indicators and athletic performance in 11-15 Year-old children. Hrvat. Sportskomed. Vjesn., 23:35-44, 2008.

Dietz, W. H. Jr. \& Gortmaker, S. L. Do we fatten our children at the television set? Obesity and television viewing in children and adolescents. Pediatrics, 75(5):807-12, 1985.

Dinarevic, S.; Brankovic, S. \& Hasanbegovic, S. Relation of diet and physical activity to obesity in children in elementary schools. J. Health Sci., 1:44-9, 2011.

Epstein, L. H. \& Goldfield, G. S. Physical activity in the treatment of childhood overweight and obesity: current 
evidence and research issues. Med. Sci. Sports Exerc., 31(11 Suppl.):S553-9, 1999.

Jakimaviciene, E. M. \& Tutkuviene, J. Trends in body mass index, prevalence of overweight and obesity in preschool Lithuanian children, 1986-2006. Coll. Antropol., 31(1):79-88, 2007.

Kirchengast, S.; Schober, E.; Waldhör, T. \& Sefranek, R. Regional and social differences in body mass index, and the prevalence of overweight and obesity among 18 year old men in Austria between the years 1985 and 2000. Coll. Antropol., 28(2):541-52, 2004.

Kirchengast, S. \& Marosi, A. Gender differences in body composition, physical activity, eating behavior and body image among normal weight adolescents--an evolutionary approach. Coll. Antropol., 32(4):1079-86, 2008.

Milanovic, S. M.; Ivankovic, D.; Uhernik, A. I.; Fister, K.; Peternel, R. \& Vuletic, S. Obesity--new threat to Croatian longevity. Coll. Antropol., 36(Suppl. 1):113-6, 2012.

Nikolaidis, P. T. Physical fitness is inversely related with body mass index and body fat percentage in soccer players aged 16-18 years. Med. Pregl., 65(11-12):470$5,2012$.

Rogulj, N.; Kovacevic, Z.; Utrobicic, I.; Krstulovic, H. \& Jukic, J. Body Mass Index in male and female students with a difference in kinesiological engagement. Zivot $i$ skola, 57(25):100-107, 2011.

Skinner, A. C.; Mayer, M. L.; Flower, K. \& Weinberger, M. Health status and health care expenditures in a nationally representative sample: how do overweight and healthyweight children compare? Pediatrics, 121(2):e269-77, 2008.

Steinberger, J.; Daniels, S. R.; American Heart Association Atherosclerosis, Hypertension, and Obesity in the Young Committee (Council on Cardiovascular Disease in the Young) \& American Heart Association Diabetes Committee (Council on Nutrition, Physical Activity, and Metabolism). Obesity, insulin resistance, diabetes, and cardiovascular risk in children: an American Heart Association scientific statement from the Atherosclerosis, Hypertension, and Obesity in the Young Committee (Council on Cardiovascular Disease in the Young) and the Diabetes Committee (Council on Nutrition, Physical Activity, and Metabolism). Circulation, 107(10):1448-53, 2003.
Sujoldzic, A. \& De Lucia, A. A cross-cultural study of adolescents--BMI, body image and psychological wellbeing. Coll. Antropol., 31(1):123-30, 2007.

Toraman, N. F. \& Ayceman, N. Effects of six weeks of detraining on retention of functional fitness of old people after nine weeks of multicomponent training. $B r . J$. Sports Med., 39(8):565-8, 2005.

World Health Organization. Obesity: preventing and managing the global epidemic. Report of a WHO consultation. World Health Organ. Tech. Rep. Ser., 894:ixii, 1-253, 2000.

Zsidegh, P.; Photiou, A.; Mészáros, Z.; Prókai, A.; Vajda, I.; Sziva, Á. \& Mészáros, J. Body mass index, relative body fat and physical performance of Hungarian Roma boys. Kinesiol., 39(1):15-20, 2007.

\author{
Correspondence to: \\ Alen Kapidzic \\ Faculty of Physical Education and Sport \\ University of Tuzla \\ 2. Oktobra br.1, 75000 \\ Tuzla \\ BOSNIA AND HERZEGOVINA
}

Email: alen.kapidzic@untz.ba

Received: 06-06-2014

Accepted: 02-01-2015 